\title{
Optimizing an Octane Number of Motor Gasoline (MOGAS) 91 RON with Blending Methods
}

\author{
Ahmad Mustafid Miftahul Huda*, Subagjo Wakimin dan Selvia Sarungu' \\ STT Migas Balikpapan, Jl. Soekarno-Hatta KM 8, Karangjoang, Balikpapan, East Kalimantan \\ *Email: mustafid13@gmail.com
}

\begin{abstract}
Motor Gasoline (MOGAS) that serves as modifiers thermal energy into mechanical energy with a Research Octane Number (RON) of 91 was produced by mixing (blending) of two components. RON are high is one of MOGAS specifications needed for good engine performance. To obtain a MOGAS with high RON usually needs additional materials, chemical components. In this work, we don't need any additional materials to increase the RON. In the field of oil and gas blending method is a method that is widely used to acquire new products that are superior and achieve quality standards. The components used in blending these are products with a value of RON 88 and 92. Examination of specific gravity (ASTM D1298) was conducted to obtain specific gravity (SG) and temperature observations (T), while the ASTM D86 distillation examination was conducted to determine the components in materials. The results showed that the product specifications in accordance with the existing products on the market. The acquisition of distillate reached $95 \%$ with losses of about $3.9 \%$, and the residue of $1.1 \%$.
\end{abstract}

Keywords: Motor Gasoline (MOGAS), Blending Methods, Distillation

\section{INTRODUCTION}

The development of Indonesian transportation vehicles integrated with the economic development. The activity of transportation including of people and things movement depends on the transportation vehicles. Today, Indonesian transportation vehicles are almost entirely full of fuel oil designed, private or public transportation. Technology improvement affected to the higher specifications of fuel oil to be applicable to the machine, additionally for the degradation issue of the environmental causing by emissions product of fuel.

MOGAS is a complex mixture of liquid hydrocarbons, flammable and evaporates. The composition of MOGAS can reach hundreds of different natural components (such as benzene and toluene) and also some additives such as Methyl Tertiary Butyl Ether (MTBE) [1]. The composition of the carbon atoms in the hydrocarbon-forming MOGAS between 412 , with a range of distillate ranging from $30-225^{\circ} \mathrm{C}$ at atmospheric pressure ${ }^{[2]}$. Physically of MOGAS function is to convert thermal energy to mechanical work. The energy obtained from the combustion process, while the process of combustion and energy changes can be carried out inside and outside the engine ${ }^{[3]}$. RON suggests that the similarity or equivalence performance of a fuel MOGAS with the capabilities provided by a mix \% volume of isooctane and normal heptane were tested using standard CFR engine $\mathrm{F}{ }^{[4]}$.

The effects of octane number were investigated and reported, on the engine performance ${ }^{[5]}$, on the effective power and fuel consumption ${ }^{[6]}$, on exhaust emissions ${ }^{[7]}$, and on the performance and exhaust emissions were studied using the carburetor gasoline engine ${ }^{[8]}$. The additive material used to increase RON has an influence the emissions ${ }^{[9]}$.

The kinds of Indonesian motor gasoline (MOGAS) products, 88 Research Octane Number (RON), 90 RON, $92 \mathrm{RON}$, and $95 \mathrm{RON}$, is applied to the specific machine design. Higher 
RON of types affected to higher performance of machine, price, technology, and long perform. A Machine designed for transportation vehicle for injections systems is recommended with the minimum 90 RON of fuel.

The research which completed is to produce MOGAS 91 RON by blending component of MOGAS 88 RON and MOGAS 92 RON. The blending of these raw materials must be simulated in the mathematical theory. The purpose of the research is conducted of MOGAS $91 \mathrm{RON}$ and to find the optimum of the material balance of raw materials, for the aspect of economic, quality products and the process of production.

The method of mixing (blending) have been conducted by various researchers in the field of oil and gas, especially to acquire new products that are superior, both excel in the oxidative stability ${ }^{[10]}$, their superior engine performance, reached the quality standard ${ }^{[11]}$. The mixing of the components can be made by heating and without heating, and occur by chemical or physical (mechanical).

\section{METHODS}

The materials used in producing MOGAS $91 \mathrm{RON}$ are the raw material that's been marketed. This is to minimize the occurrence of circumstances off-spec. Off-spec is a condition of the product that is not permitted to be used. Some terms of a product can be used as the value of the SG and distillation so have the suitability criteria that were published by the Indonesian's Government. Materials used for blending is the product of MOGAS from PERTAMINA, Premium (RON 88) and Pertamax (RON 92). Comparison of calculation of basic ingredients begins with a consideration of the economic basic materials through equations ON blending.

$$
O N=\frac{(A \times 88)+(B \times 92)}{100}
$$

$A$ and $B$ represent the value of the base material, Premium, and Pertamax, $A+B=100$. So from the calculation, the ratio between $\mathrm{A}: \mathrm{B}$ amounted to $1: 3$. The next step is to measure each SG ASTM D-1298 ${ }^{[12]}$ of the base material, although basically already known from the specification MOGAS has been issued by the director general of the Energy and Mineral Resources of Indonesia.

After the SG are known, then performed testing distillation ASTM D86 ${ }^{[12]}$ for each raw material. Subsequent measurement is done by a blending ratio of SG that is already set, then performed testing blending MOGAS distillation.

The first examination of specific gravity, ASTM D1298 to obtain Specific Gravity (SG) and temperature $(\mathrm{T})$ observation. The second is examination Distillation ASTM D86 to determine the components present in the sample.

\section{RESULT AND DISCUSSION}

Examination for Premium and Pertamax SG, SG observation values obtained at $63^{\circ} \mathrm{F} 0.757$ and 0.760 at $82^{\circ} \mathrm{F}$. While the results of the SG Blending with composition $1: 3,125 \mathrm{ml}$ : $375 \mathrm{ml}$, obtained SG value of 0.765 at $63{ }^{\circ} \mathrm{F}$. So we get the value of SG $60 / 60{ }^{\circ} \mathrm{F}$ for the MOGAS products, Premium, Pertamax, blending, respectively amounting 0.7585, 0.7707, 0.7665 .

The distillation is performed using ASTM D86 with a volume of $100 \mathrm{ml}$. Moreover, the process of distillation using a coolant which serves to reduce losses on distillate. 
Table 1. The Result of Distillation ASTM D86

\begin{tabular}{cccc}
\hline \multirow{2}{*}{$\%$ Volume } & \multicolumn{3}{c}{ Temperature $\left({ }^{\mathbf{0}} \mathbf{C}\right)$} \\
\cline { 2 - 4 } & Blending & Premium & Pertamax \\
\hline IBP & 47 & 45 & 50 \\
$\mathbf{5}$ & 60 & 62 & 64 \\
$\mathbf{1 0}$ & 68 & 65 & 69 \\
$\mathbf{2 0}$ & 79 & 73 & 82 \\
$\mathbf{3 0}$ & 89 & 82 & 95 \\
$\mathbf{4 0}$ & 100 & 91 & 103 \\
$\mathbf{5 0}$ & 110 & 102 & 110 \\
$\mathbf{6 0}$ & 120 & 114 & 124 \\
$\mathbf{7 0}$ & 131 & 126 & 136 \\
$\mathbf{8 0}$ & 145 & 140 & 149 \\
$\mathbf{9 0}$ & 164 & 162 & 172 \\
$\mathbf{9 5}$ & 196 & 175 & 195 \\
\hline FBP & 198 & 207 & 206 \\
\hline
\end{tabular}

Based on Table 1, we can draw a graphic of distillate result. Figure 1 representing the distillation process of Premium (88). Figure 2 representing Pertamax (92), and Figure 3 showing the distillation process of blending product. Initial boiling point (IBP) for premium is lowest than the other, it's mean that premium will vaporize first between the products.

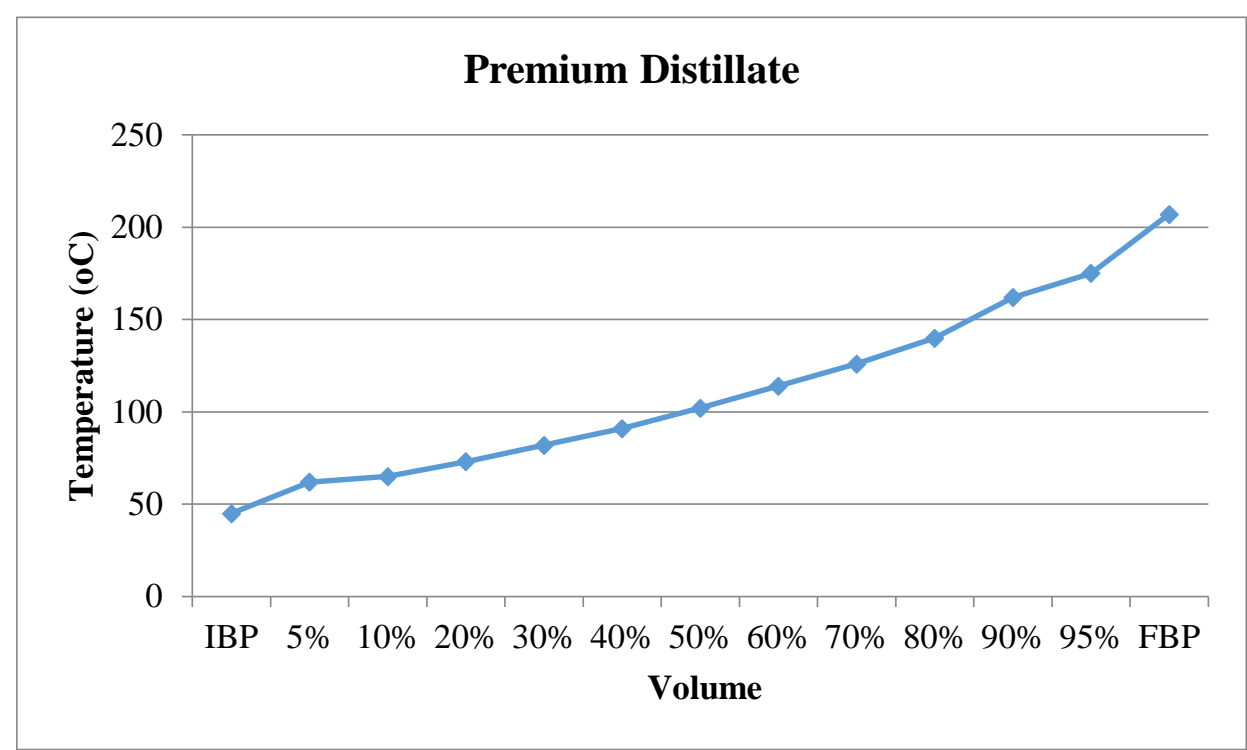

Figure 1. (Colour online) Distillation result of Premium, vertical axis for the temperature $\left({ }^{\circ} \mathrm{C}\right)$ and horizontal axis is percentage of volume recovery

The volume of residue for each raw material shown in Table 2, examined the residue is 1 $\mathrm{ml}$ and percentage of loses $3 \mathrm{ml}$. It's different with the blending product results. The residue of a blending product is $1.1 \mathrm{ml}$ and percentage of loss is $3.9 \mathrm{ml}$. The process of distillation is not clearly perfect, because of there still a percentage of loss, but that is fair enough 


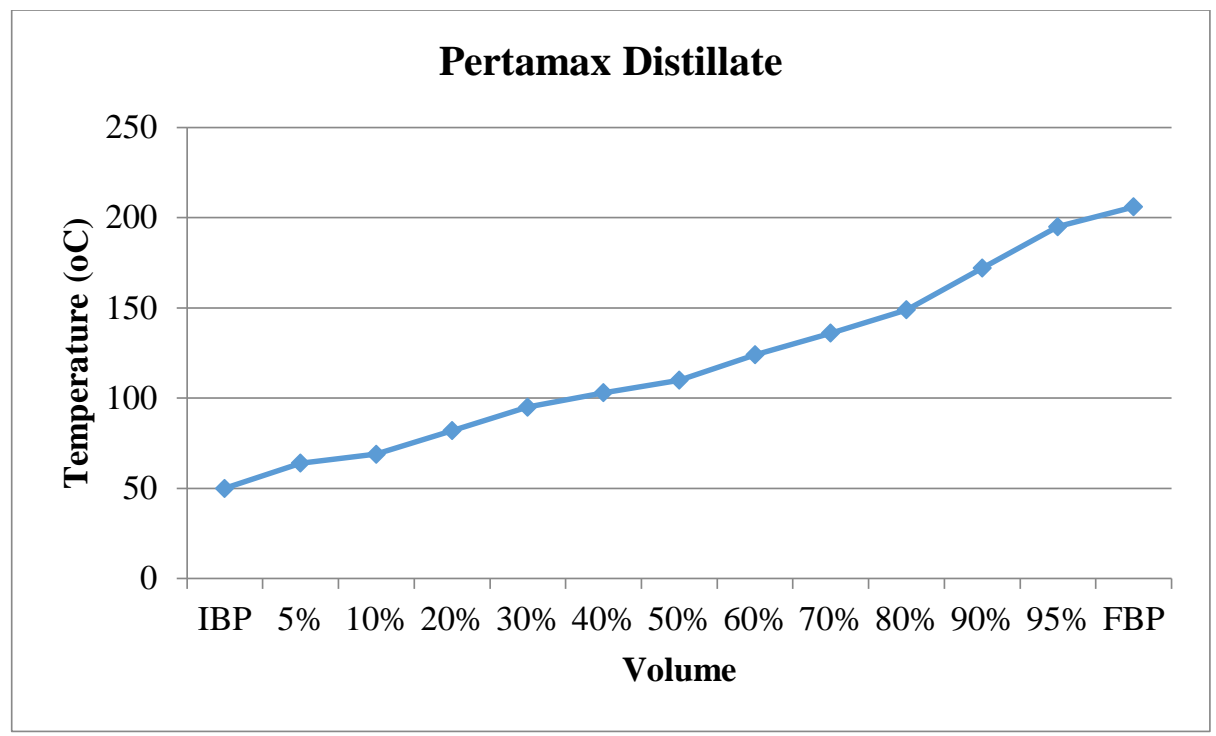

Figure 2. (Colour online) Distillation result of Pertamax, vertical axis for the temperature $\left({ }^{\circ} \mathrm{C}\right)$ and horizontal axis is percentage of volume recovery

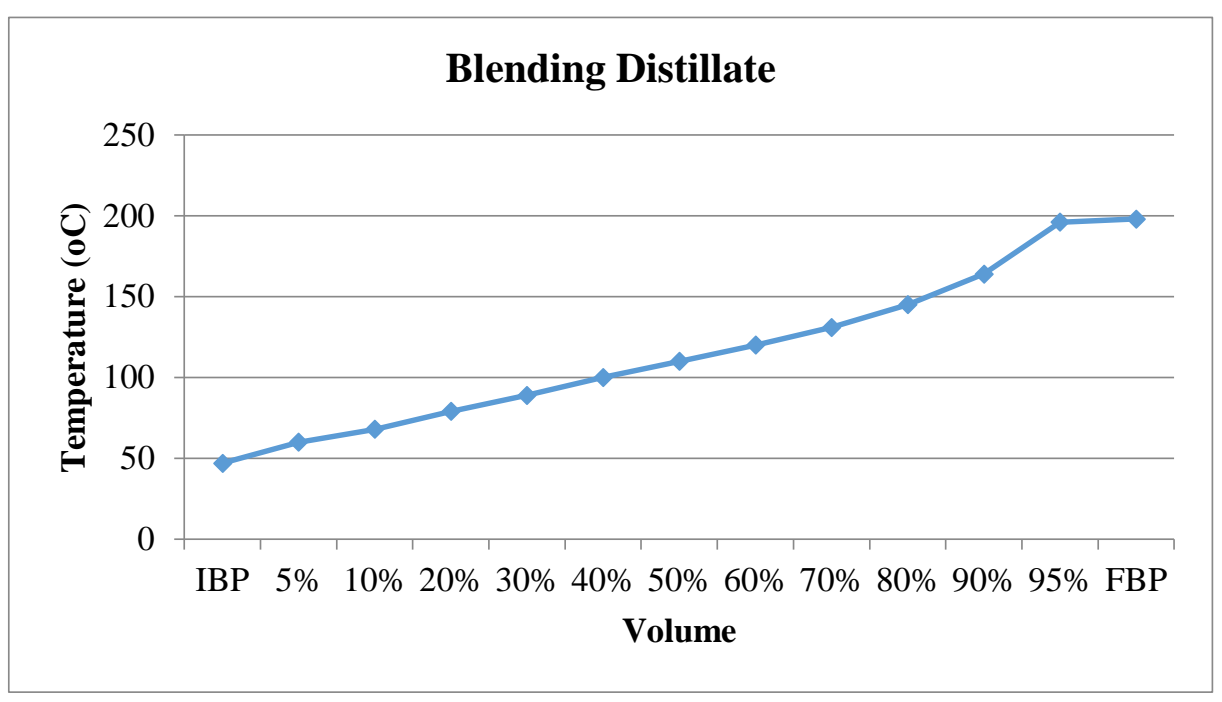

Figure 3. (Colour online) Distillation result of Blending Product, vertical axis for the temperature $\left({ }^{\circ} \mathrm{C}\right)$ and horizontal axis is percentage of volume recovery

Table 1. Percentage results of volume

\begin{tabular}{lccc}
\hline Volume & Premium & Pertamax & Blending Product \\
\hline Distillate $(\mathrm{ml})$ & 96 & 96 & 95 \\
Residue $(\mathrm{ml})$ & 1 & 1 & 1,1 \\
Loses $(\%)$ & 3 & 3 & 3,9 \\
\hline
\end{tabular}

\section{CONCLUSION}

The blending of two raw materials, premium, and pertamax, can produce a 91 RON product. Production of MOGAS 91 RON should be On-Spec because the Specification of MOGAS available to use, depending on the regulation of government. 3,9 \% of volume loss in the distillation process, shown that the process isn't perfect, so the product should be review deeply. 


\section{ACKNOWLEDGEMENTS}

We deeply thank STT Migas Balikpapan for the funding of this research and used the Refinery Laboratory. We also thank PERTAMINA RUV Balikpapan for the equipment process. We thank the Indonesian ministry of law and human rights (KEMENKUMHAM) for providing intellectual property rights for this work

\section{REFERENCES}

1 Al-Ghouti, M.A., Al-Degs Y. S., \& Amer M. 2008. Determination of motor gasoline adulteration using FTIR spectroscopy and multivariate calibration. Talanta, 76 (5), 11051112.

2 Takeshita, E. V., Rezende R. V. P., de Souza S. M. A. G. U., \& de Souza A. A. U. 2008 Influence of solvent addition on the physicochemical properties of Brazilian gasoline. Fuel, 87 (10), 2168-2177.

3 Granovskii, M., Dincer, I., \& Rosen, M. A. 2006. Life cycle assessment of hydrogen fuel cell and gasoline vehicles. Int. J. Hydrogen Energy, 31 (3), 337-352.

4 Foong, T. M., Morganti, K. J., Brear, M. J., da Silva, G., Yang, Y., \& Dryer, F. L. 2014. The octane numbers of ethanol blended with gasoline and its surrogates. Fuel, 115, 727739.

5 Chanchaowna, S. 1999. The effect of gasoline octane number on engine performance. Research Report. King Mongkut's University of Technology, Thailand.

6 Sudsanguan, P., \& Chanchaowna, S. 1999. Using higher octane rating gasoline than engine requirement: loss or gain. Research Report, King Mongkut's University of Technology, Thailand.

7 Sayin, C., \& Kilicaslan, I. 2003. Influence of octane number on exhaust emission in a sparkignition engines. The First International Exergy, Energy and Environment Symposium, Izmir/Turkey, 184-189.

8 Sayin, C., Kilicaslan, I., Canakci, M., \& Ozsezen, N. 2005. An experimental study of the effect of octane number higher than engine requirement on the engine performance and emissions. Appl. Therm. Eng., 25 (8), 1315-1324.

9 Sayın C., \& Kilıçaslan, İ. 2003. The effect of lead ratio on exhaust emission in a gasoline engine. Deniz Bilim. ve Mühendisliği Derg., 1 (1).

10 Marotrao, T. K. 2012. Physiochemical Properties Of Oil Blend And Their Effects On Lubrication Properties. Int. J. Adv. Eng. Res. Stud., 1 (3), 35-38.

11 Maria, K., Maxim, M., Emilia, I., \& Elizaveta, S. 2014. Optimization of High-octane Gasoline Production.

12 Nadkarni, R. A. 2007. Guide to ASTM test methods for the analysis of petroleum products and lubricants. ASTM International West Conshohocken. 